\title{
Influence of New and Old Regulation Standard for Energy Efficiency on Thermal Insulation in Serbia
}

\author{
M. Miletić, I. Miletić, E. Dolićanin, V. Nikolić
}

\begin{abstract}
Due to new policies for energy efficiency, buildings are having new thermal insulation thickness to achieve desired U-factor and energy class in energy passport. Before, the thermal insulation of the houses was $5 \mathrm{~cm}$ thick, but nowadays with new policy it needs to have higher thickness. This influences an increased cost of the house in its building phase, but actually saves money over time during years. In this paper one common Serbian house is modeled in EnergyPlus and then the thermal insulation thickness is changed. Also influence of the house orientation is discussed. Afterward, energy consumption for these houses is compared for old, refurbished and the house achieving new standard, and economic savings during the years and payback period are discussed. Results show that there is big influence of the thickness of the thermal insulation, but also that it is better to have the house oriented toward south to increase heat gains from solar energy during winter.
\end{abstract}

Keywords: Energy efficiency, Thermal insulation, EnergyPlus, Energy balance, Energy passport

\section{Introduction}

Nowadays, countries all around the world are trying to reduce the energy used for households, especially for heating and cooling. In order to do so, they are investing money in improving energy efficiency by releasing new policies, giving subvention on using more efficient equipment, sponsoring the ministry projects which are improving energy efficiency and investing in producing energy from renewable sources.

Due to new policies for energy efficiency, buildings are having new thermal insulation thickness to achieve desired U-factor and class in energy passport. Before, the thermal insulation of the houses was $5 \mathrm{~cm}$ thick, but nowadays with new policy it needs to have higher thickness (approximately $8 \mathrm{~cm}$ for old houses which are refurbished, and $11 \mathrm{~cm}$ for new houses). This influences an increased cost of the house in its building phase, but actually saves money over time during years. Improving thermal insulation is first step toward the reaching zero net energy buildings.

Manuscript received February 14 ; accepted June 25

M. Miletić and I. Miletić are with the Faculty of Engineering, Kragujevac, Serbia; E. Dolićanin and V. Nikolić are with the State University of Novi Pazar, Novi Pazar, Serbia. 
Bojic et al. investigated influence of the thermal insulation position in building on a space cooling of high rise building in Hong Kong [3]. They used different thickness of the thermal insulation layers and concrete. They also used different materials for the thermal insulation layer. They concluded that the best results are achieved when the thermal insulation layer is placed either inside or outside. Bojic and Loveday researched on building thermal behaviour of the insulation/masonry distribution in a three-layered construction [4]. Sanea and Zedan improved thermal performance of building walls by optimizing the insulation layer distribution and thickness for same thermal mass [1]. Miletic et al. investigated optimal thickness of the thermal insulation layer by type and embodied energy in thermal insulation in order to minimize total primary energy used in house [10].

Bojic et al [5] investigated thermal insulation in cooled spaces in high residential buildings in Hong Kong. Lam et al [7] discussed the energy efficiency in different climates. In one of his paper Lam et al [8] made multiple regression models for energy use in airconditioned office buildings in different climates.

Andersson et al. were first to research the impact of building orientation on residential heating and cooling [2]. The study was carried out for 25 climates in the United States. They used software program BLAST to analyze the influence of the orientation. They concluded that in these regions, it is better to have windows oriented towards south or north than to east or west. Yohanis and Norton investigated useful solar gains in multi-zone nondomestic buildings as a function of building orientation and thermal time constant [13]. Morrissey et al. experimented with building orientation and its influence on affordable passive solar design [12]. Mitchell et al. investigated influence of building orientation on climate weathering cycles in Hamptonshire, UK [11].

In this paper one common Serbian house is modeled in EnergyPlus and then the thermal insulation thickness is changed. Also influence of the house orientation is discussed. Afterward, energy consumption for these houses is compared for old, refurbished and the house achieving new standard, and economic savings during the years and payback period are discussed. Results show that there is big influence of the thickness of the thermal insulation, but also that it is better to have the house oriented toward south to increase heat gains from solar energy during winter.

\section{House description}

\subsection{Model of the house}

Investigated house model is located in Kragujevac and it presents house for one family of four members. During the winter house is heated by using electric baseboard radiator, and during the summer house is cooled by air conditioners. House is shown on Figure 1.

House basement plane is given on Figure 2. It can be seen that house has 1 living room, 2 bedrooms, kitchen, corridor, toilet and WC. Area of conditioned space is $90 \mathrm{~m}^{2}$.

Originally, windows of the living room and bedroom 1 are oriented toward north. In Table 1 area of each room is given. All rooms are conditioned except the roof. For the 
Influence of new and old regulation standard for energy efficiency on thermal insulation in Serbia 133

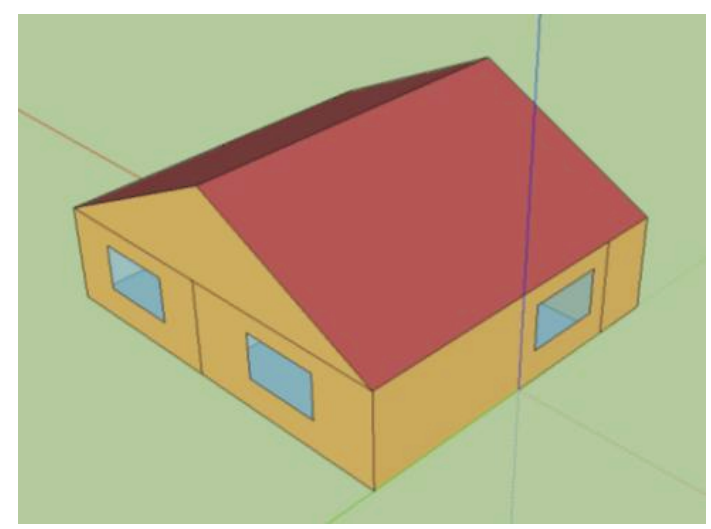

Fig. 1. Investigated building

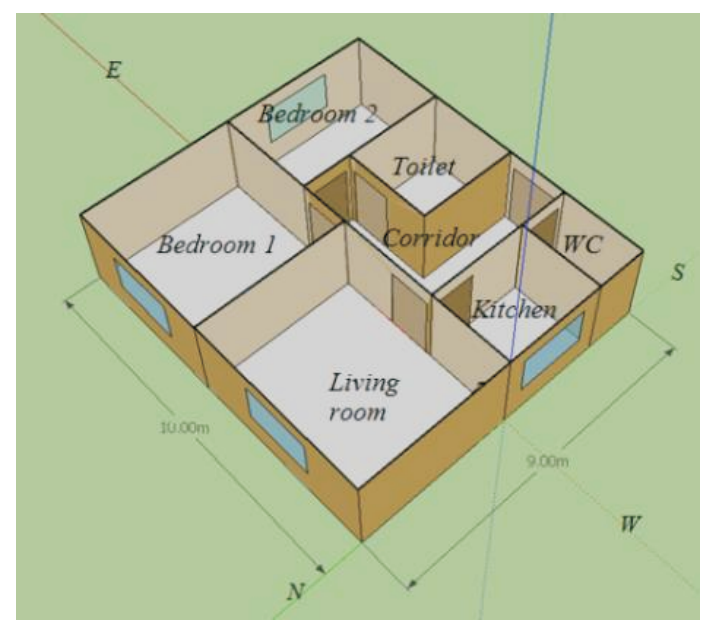

Fig. 2. House plan

purpose of the paper house is rotated by $180^{\circ}$ in some cases, so the living room and bedroom are oriented toward south.

Table 1. Area of the rooms, $m^{2}$

\begin{tabular}{|c|c|c|c|c|c|c|c|}
\hline Livingroom & Bedroom 1 & Kitchen & WC & Bedroom 2 & Toilet & Corridor & Roof \\
\hline 24.75 & 20.25 & 7.5 & 3.75 & 13.5 & 8.1 & 12.15 & 90 \\
\hline
\end{tabular}

\subsection{House location and weather description}

House is located in Kragujevac, Serbia latitude $44^{\circ} 02 \mathrm{~N}$, longitude $20^{\circ} 56 \mathrm{E}$ and the height above the sea at $185 \mathrm{~m}$. Monthly average temperature is ranging from $-0.1{ }^{\circ} \mathrm{C}$ in January to $20.6^{\circ} \mathrm{C}$ in July. Average temperature during the year is $16.7^{\circ} \mathrm{C}$. Absolute maximum temperature during the year is $40^{\circ} \mathrm{C}$ in July and the absolute minimum temperature is - 
$27.3^{\circ} \mathrm{C}$ in January [18]. House has ventilation rate of 2 changes per hour.

\subsection{Electric equipment and lighting}

Electric equipment consists of the normal equipment for one household like TVs, radios, computers, oven, fridge, washing machine, boiler... Usage of this equipment is set according to the needs of one family during one year, depending on the season and time of the day.

Lighting in the house is presented in Table 2. It is set also according to the season and time of day.

Table 2. Total light power by room, $\mathrm{W}$

\begin{tabular}{|c|c|c|c|c|c|c|}
\hline Livingroom & Corridor & Toilet & Bedroom 1 & Bedroom 2 & Kitchen & WC \\
\hline 160 & 60 & 60 & 100 & 100 & 100 & 60 \\
\hline
\end{tabular}

\subsection{Heating and cooling of the house}

According to the Serbian heating codes [14], the desired air temperatures are set in the living room and the bedrooms at $20^{\circ} \mathrm{C}$, and the bathroom at $22^{\circ} \mathrm{C}$, respectively. House is heated from 6:00 to 22:00. From 22:00-06:00 in living rooms and bedrooms setback temperature is $16^{\circ} \mathrm{C}$. Electrical heaters with thermostatic valves heat the entire house. The heating system is designed according to the standard procedures defined in [14]. Also according to these procedures temperatures in $\mathrm{WC}$ should be $15^{\circ} \mathrm{C}$ and in hallways $15^{\circ} \mathrm{C}$. By new standard for energy efficiency $\mathrm{U}$-factor in new houses should be $U<0.3$, and for the houses which are refurbished $U<0.4$ [9]. In most cases, the desired air temperatures are met in the first half of an hour of the heating start. The thermostatic valves thus save energy by turning off the heaters when the air temperature is above the desired value, and then by turning on the heaters when the air temperature falls below the desired value. House is heated from 15th October to 15th April. In case of cold days house is also heated.

As for cooling, only conditioned rooms are living room, bedrooms, and kitchen which all have 1 window. There is no need for cooling of the toilet, wc and corridor. Setpoint temperatures for cooling from 6 am to $24 \mathrm{pm}$ is at $24^{\circ} \mathrm{C}$. House is cooled during hot seasons.

\subsection{Thermal insulation}

Wall construction is taken from URSA [19], and they are common in Serbia. External construction is shown in Figure 3. In this case thermal insulation layer is placed outside.

Used thermal insulation is polystyrene. U-factor values for this research by thermal insulation layer thickness are presented in Figure 4. 
Influence of new and old regulation standard for energy efficiency on thermal insulation in Serbia 135

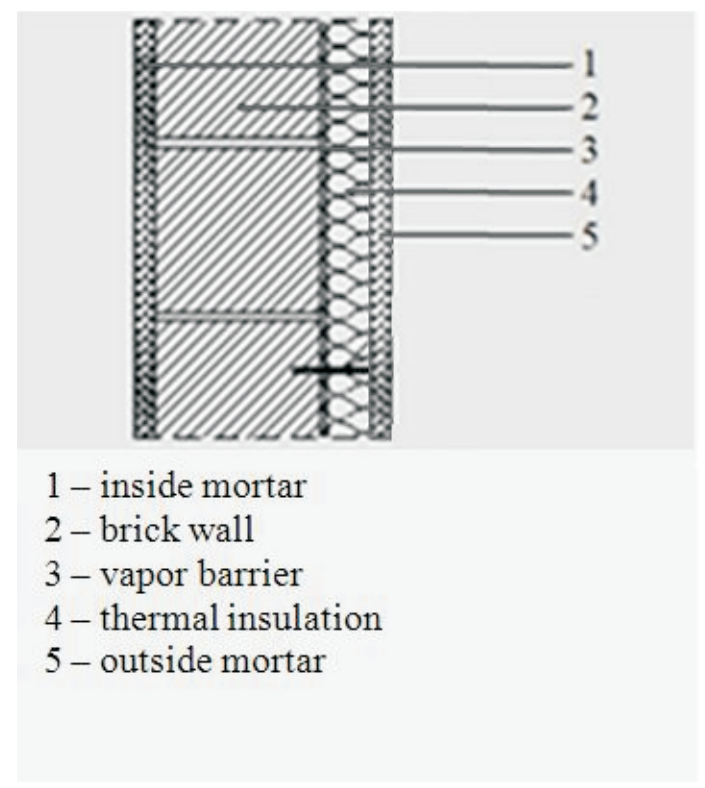

Fig. 3. External wall construction

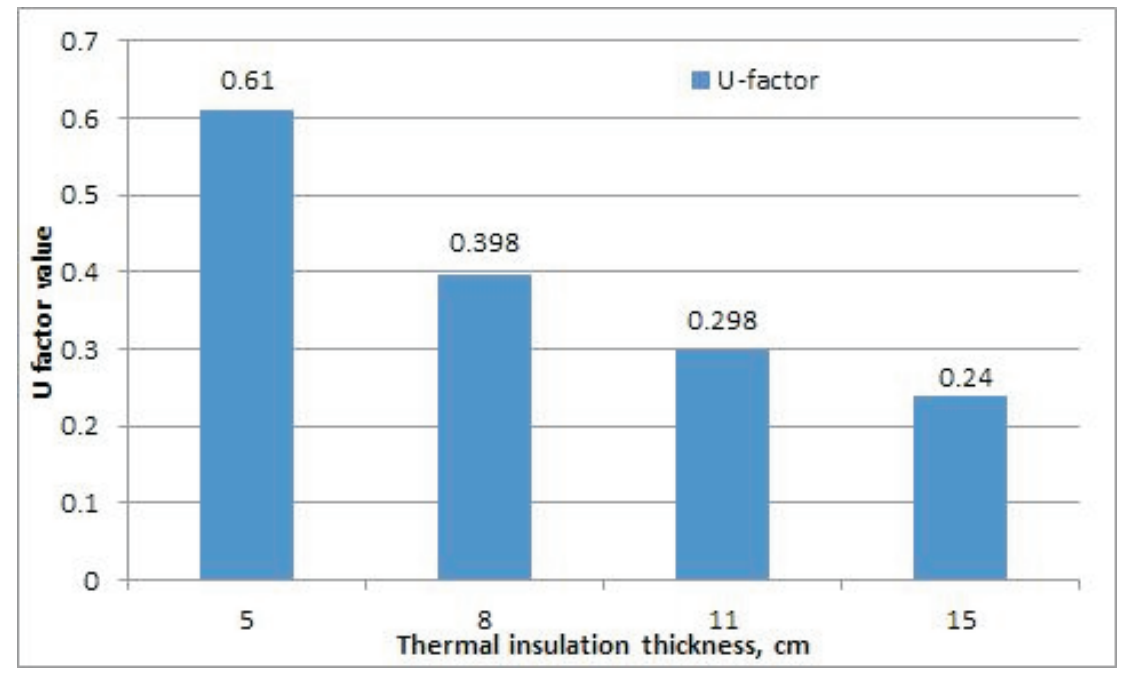

Fig. 4. U-factor of external wall depending on the thermal insulation thickness

\subsection{New regulation for thermal insulation}

New regulation demands that newly built houses have external wall U-factor less than $U<$ 0.3 , and $U<0.4$ for refurbished houses. It also demands that houses must be at least in $\mathrm{C}$ energy class. This means that refurbished house has less than a $75 \mathrm{kWh} / \mathrm{m}^{2} \mathrm{a}$, and new house has less than a $65 \mathrm{kWh} / \mathrm{m}^{2}$ a (Table 3). 
Table 3. Energy class for houses by new regulation[15]

\begin{tabular}{|c|c|c|c|}
\hline Family house & & New & Existing \\
\hline Energy class & $Q_{H, n d, r e l}[\%]$ & $Q_{H, n d}\left[\mathrm{kWh} /\left(\mathrm{m}^{2} a\right)\right]$ & $Q_{H, n d}\left[\mathrm{kWh} /\left(\mathrm{m}^{2} a\right)\right]$ \\
\hline$A+$ & $\leq 15$ & $\leq 10$ & $\leq 12$ \\
\hline$A$ & $\leq 25$ & $\leq 17$ & $\leq 20$ \\
\hline$B$ & $\leq 50$ & $\leq 33$ & $\leq 38$ \\
\hline$C$ & $\leq 100$ & $\leq 65$ & $\leq 75$ \\
\hline$D$ & $\leq 150$ & $\leq 98$ & $\leq 113$ \\
\hline$E$ & $\leq 200$ & $\leq 130$ & $\leq 150$ \\
\hline$F$ & $\leq 250$ & $\leq 163$ & $\leq 188$ \\
\hline$G$ & $\leq 250$ & $\leq 163$ & $\leq 188$ \\
\hline
\end{tabular}

\subsection{Electricity cost}

Electricity cost in this case is for users with two tariffs which are mostly used in civil buildings [16]. Electricity price is given in Figure 5 by tariffs and zones. Lower tariff is used during night so in this case when heating and cooling is considered high tariff will be used in most situations. Green zone is for users who are spending less than $350 \mathrm{kWh}$ per month, blue zone is for users who are spending from $350-1600 \mathrm{kWh}$ per month and red zone is for users who are spending over $1600 \mathrm{kWh}$ per month.

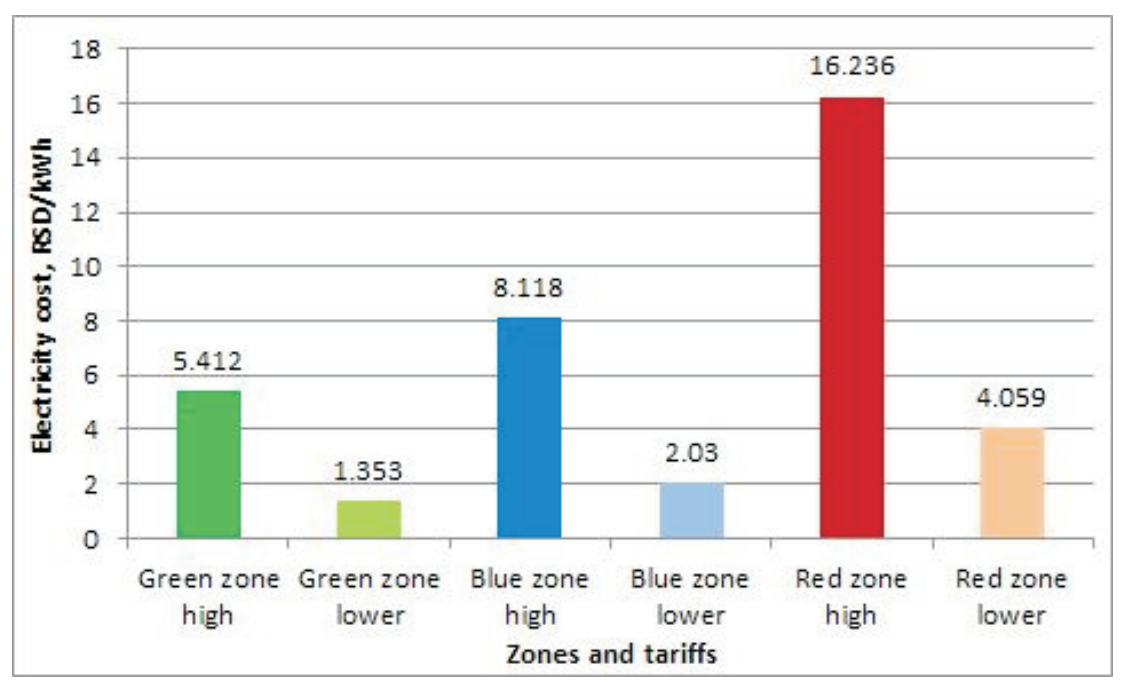

Fig. 5. Electricity price for civil use in Serbia by tariff in RSD per kWh

\subsection{Thermal insulation cost}

Price for thermal insulation is given in Table 4. This price was active during April of 2014. House has $120 \mathrm{~m}^{2}$ of external walls. Cost of 2 workers is considered as $6000 \mathrm{RSD}$ for 
Influence of new and old regulation standard for energy efficiency on thermal insulation in Serbia 137

refurbishment works

Table 4. Thermal insulation cost

\begin{tabular}{|c|c|}
\hline Insulation layer thickness, $\mathrm{cm}$ & Thermal insulation cost, $\mathrm{RSD} / \mathrm{m}^{2}$ \\
\hline 5 & 263 \\
\hline 8 & 421 \\
\hline 11 & 579 \\
\hline 15 & 789 \\
\hline
\end{tabular}

\section{Mathematical model}

\subsection{EnergyPlus}

To simulate heating, cooling, lighting, ventilation, water network and other energy flows in a built environment, EnergyPlus can be used [6]. EnergyPlus takes into account all factors that influence thermal loads in the building, such as they are electricity devices, lighting, pipes in the building, solar radiation, wind, infiltration, and shading. This software is used to simulate energy behavior of the investigated house [17]. For this house, the geometry is defined outside EnergyPlus by using Google SketchUp with an OpenStudio plug-in [20]. In the Google SketchUp environment, this geometry is shown in Figure 1 and 2.

\subsection{Mathematics}

The annual operative heat consumption of the house presents an annual heat consumption of the heaters in the house to sustain the desired air temperature, as shown in the following equation:

$$
E_{u, h}=\sum_{d=1}^{365} \sum_{h=1}^{24} E_{u, h, d}
$$

Where $E_{u, h, d}$ stands for the heat consumption in hour h, on day d.

The annual operative cooling consumption of the house presents an annual cooling consumption of the heaters in the house to sustain the desired air temperature, as shown in the following equation:

$$
E_{u, c}=\sum_{d=1}^{365} \sum_{h=1}^{24} E_{u, c, d}
$$

Where $E_{u, c, d}$ stands for the cooling consumption in hour h, on day d.

Energy intensity is calculated when the annual consumption is divided by area of the house. This is given in following equation:

$$
Q_{H, n d}=\left(E_{u c}+E_{u c}\right) / 90
$$


Payback period is calculated as money invested in additional thermal insulation divided by annual savings on energy consumption given by money paid for electricity:

$$
R_{\text {payback }}=\left(M_{\text {insulation }}+M_{\text {workers }}\right) / M_{\text {savings,annual }}
$$

\section{Results and discussions}

\subsection{House consumption oriented toward north}

Results show that when thermal insulation layer thickness was increased house consumption was dropping like it was expected. This is especially seen on the consumption for heating. This is presented in Figure 6 for the house oriented north.

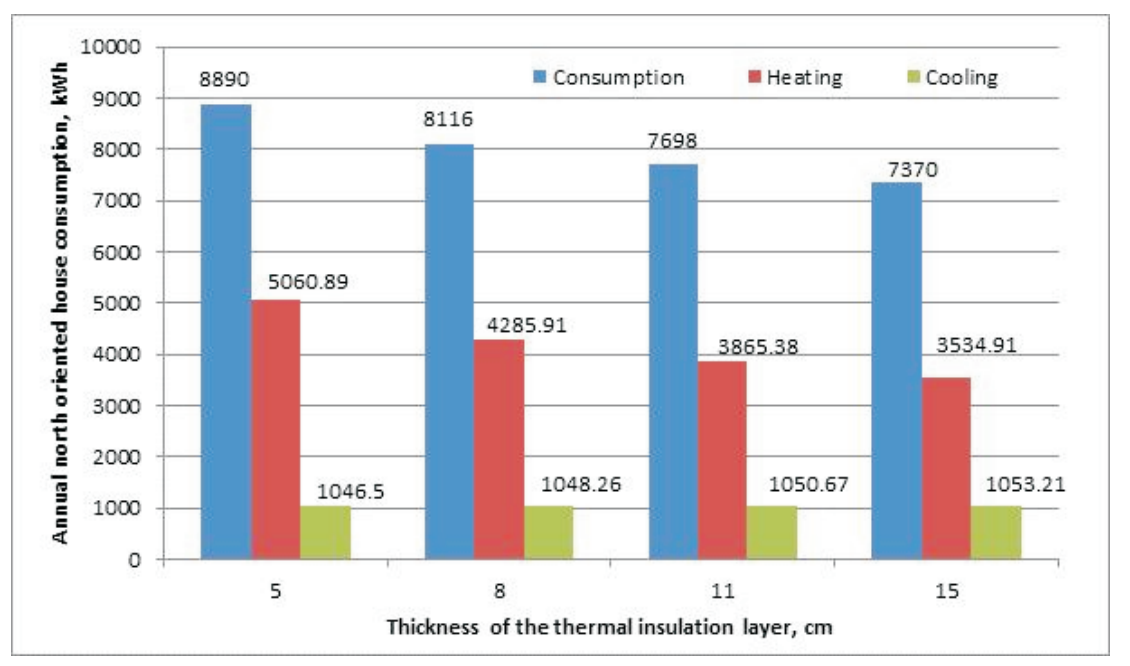

Fig. 6. Consumption of the houses oriented north with different thermal insulation thickness

In these cases consumption of electric equipment is always the same at $1554 \mathrm{kWh}$ per year, and lighting is at $1200 \mathrm{kWh}$ per year. Thermal insulation thickness has small influence on the cooling consumption as the consumption stays the same at around $1050 \mathrm{kWh}$ for all cases. But influence on the heating consumption is very big. It can be seen that house with $5 \mathrm{~cm}$ thermal insulation layer thickness is using $5061 \mathrm{kWh}$, while the house with 15 $\mathrm{cm}$ thermal insulation layer thickness is using $3535 \mathrm{kWh}$. This is saving of $31 \%$ when only heating consumption is considered. If total consumption is considered then the saving is around $17 \%$. If the old regulation $5 \mathrm{~cm}$ and the regulation for new houses $11 \mathrm{~cm}(U<0.3)$ are considered then the saving for heating consumption is $24 \%$.

If overall influence of the heating consumption on the total house consumption is considered it can be seen that in case of old regulation thickness heating consumption was involved with $57 \%$ while with $15 \mathrm{~cm}$ thickness of thermal insulation heating consumption is involved with $48 \%$. This is presented in figure 7 . 


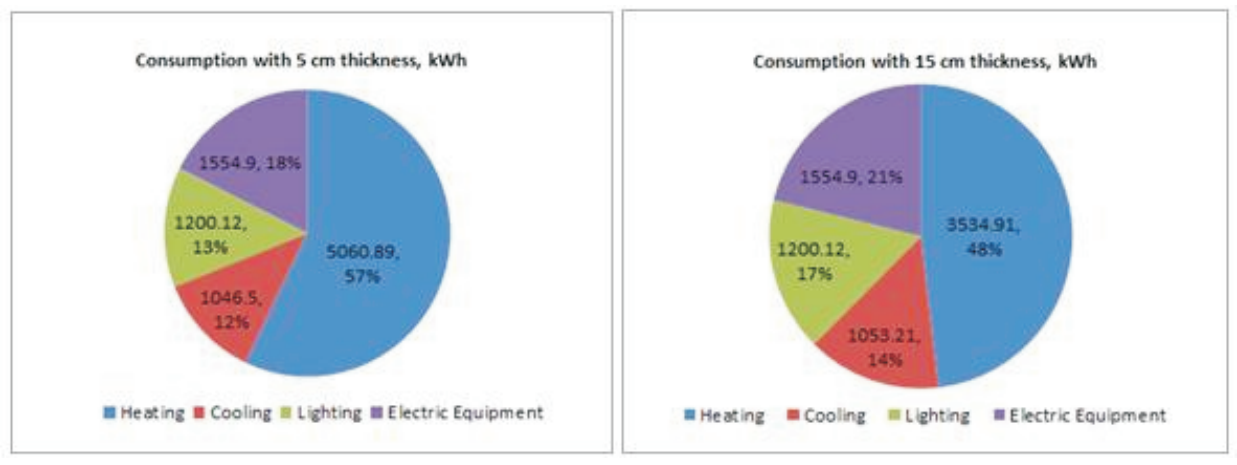

Fig. 7. Energy consumption pie at north oriented houses

\subsection{House consumption oriented toward south}

Like in case with house oriented to north in this case heating consumption is the most influenced by the thermal insulation thickness change. This can be seen in figure 8 .

In these cases consumption of electric equipment is always the same at $1554 \mathrm{kWh}$ per year, and lighting is at $1200 \mathrm{kWh}$ per year, like in previous case. Thermal insulation thickness has small influence on the cooling consumption as the consumption stays the same at around $1235 \mathrm{kWh}$ for all cases. But influence on the heating consumption is very big. It can be seen that house with $5 \mathrm{~cm}$ thermal insulation layer thickness is using $4350 \mathrm{kWh}$, while the house with $15 \mathrm{~cm}$ thermal insulation layer thickness is using $2870 \mathrm{kWh}$. This is saving of $35 \%$ when only heating consumption is considered, which is even more saving than for the case with north oriented house even though that the total house consumption is smaller. If total consumption is considered then the saving is around $18 \%$. If the old regulation 5 $\mathrm{cm}$ and the regulation for new houses $11 \mathrm{~cm}(U<0.3)$ are considered then the saving for heating consumption is $27 \%$.

If overall influence of the heating consumption on the total house consumption is considered it can be seen that in case of old regulation thickness heating consumption was involved with $52 \%$ while with $15 \mathrm{~cm}$ thickness of thermal insulation heating consumption is involved with $48 \%$. This is presented in Figure 9.

\subsection{House orientation comparison}

If houses are compared it can be seen that south oriented houses are using less energy for heating than those oriented to north. This can be seen by comparing Figures 6 and 8 . When houses with thermal insulation of $5 \mathrm{~cm}$ are compared it can be seen that south oriented house is using $710 \mathrm{kWh}$ or $14 \%$ less energy for heating. But it is using $183 \mathrm{kWh}$ more for cooling. This means that it is using $527 \mathrm{kWh}$ less or $8 \%$ of total energy needed for HVAC.

In case of $15 \mathrm{~cm}$ thermal insulation south oriented house is using $664 \mathrm{kWh}$ or $19 \%$ less energy for heating. But is using $189 \mathrm{kWh}$ more for cooling. This means that it is using 475 $\mathrm{kWh}$ less or $10 \%$ of total energy needed for HVAC. 


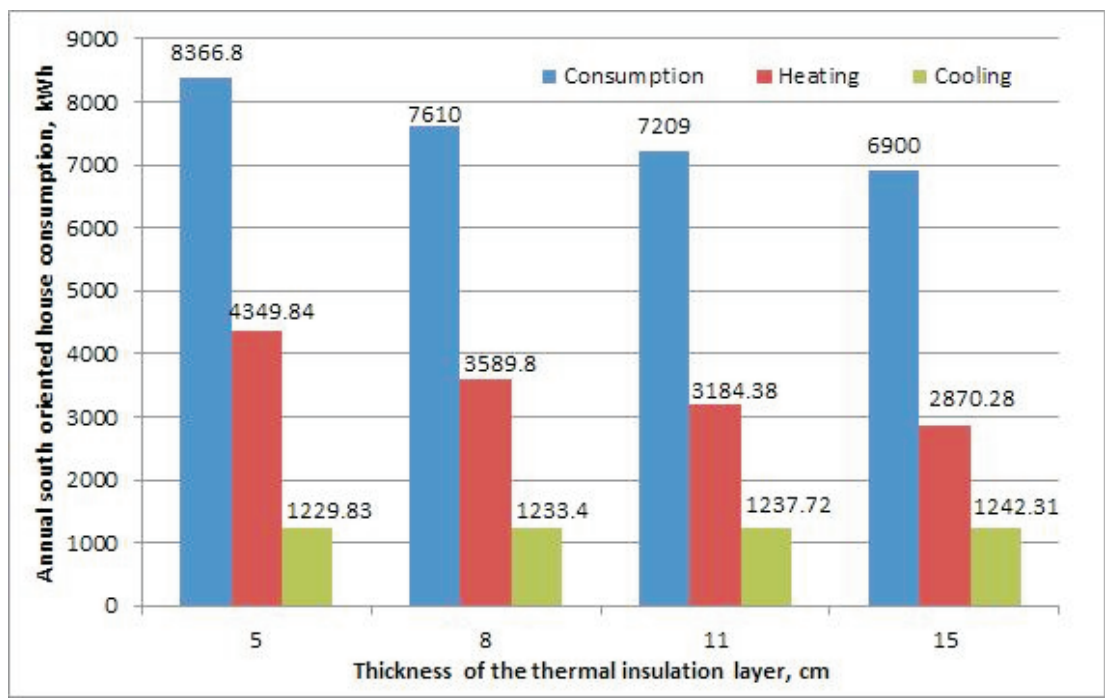

Fig. 8. Consumption of the houses oriented south with different thermal insulation thickness

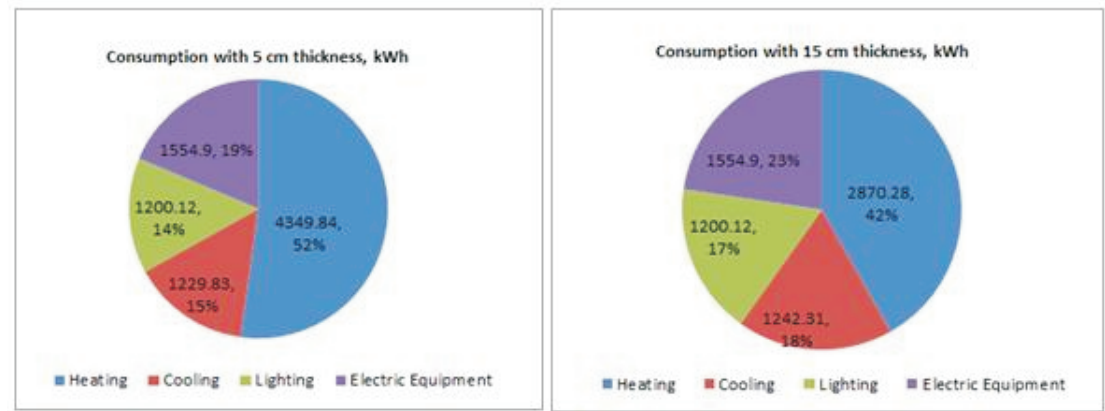

Fig. 9. Energy consumption pie at south oriented houses

On Figure 10 energy intensity per $m^{2}$ are presented.

It can be seen that all the houses are in $\mathrm{C}$ class even though that they shouldnt be by using normal calculation. This is due to fact that weather is constantly changing and that it is taken into account by this simulation. In case of normal calculation, the coldest day of the year is considered. Also, it can be noticed that intensity in case of south oriented houses is using around $5.5-6 \mathrm{kWh} / \mathrm{m}^{2}$ a less than for the house of same thickness. This is more affecting the efficient houses as there the percentage of difference is higher.

It also can be seen that houses with bigger thickness of the thermal insulation are more efficient from 16.29 to $16.88 \mathrm{kWh} / \mathrm{m}^{2}$ a when houses with $15 \mathrm{~cm}$ thermal insulation thickness are compared to house with $5 \mathrm{~cm}$ thermal insulation thickness with the same orientation of the house. 
Influence of new and old regulation standard for energy efficiency on thermal insulation in Serbia 141

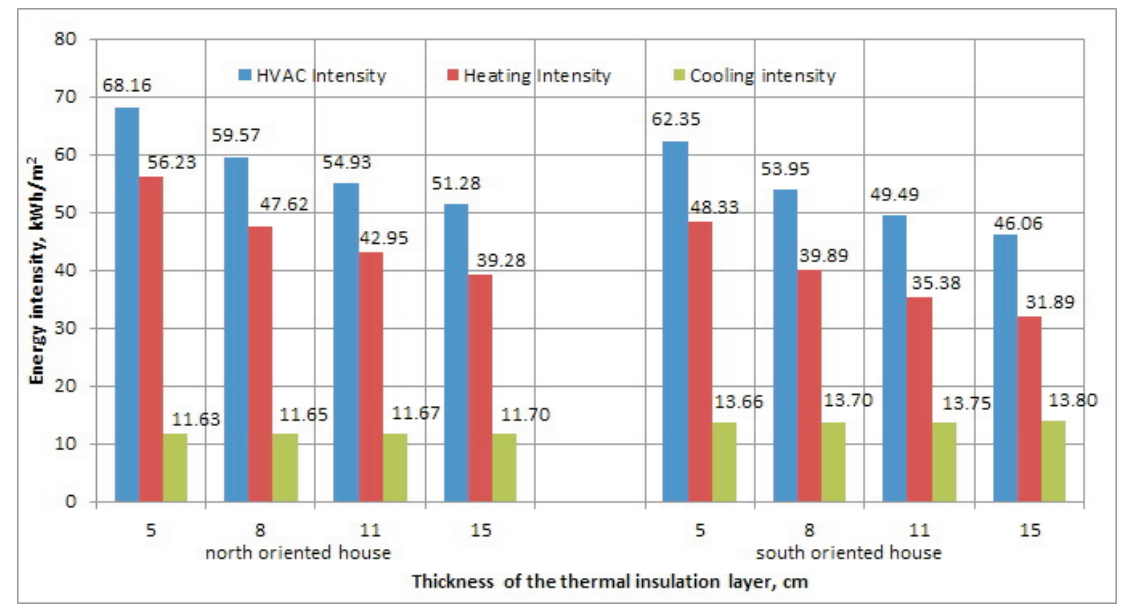

Fig. 10. Energy intensity of the houses depending on their orientation and thermal insulation thickness

\subsection{Influence of solar heat gains}

This difference between house of the north and south orientation can be explained by solar heat gains through the windows. If the house is oriented to south it gains more energy during winter and saves energy needed for heating. But this also means that it will gain more solar heat during summer which will increase cooling consumption. But more energy is saved on annual level if the house is oriented toward south. On Figure 11 solar heat gains are presented throughout whole year.

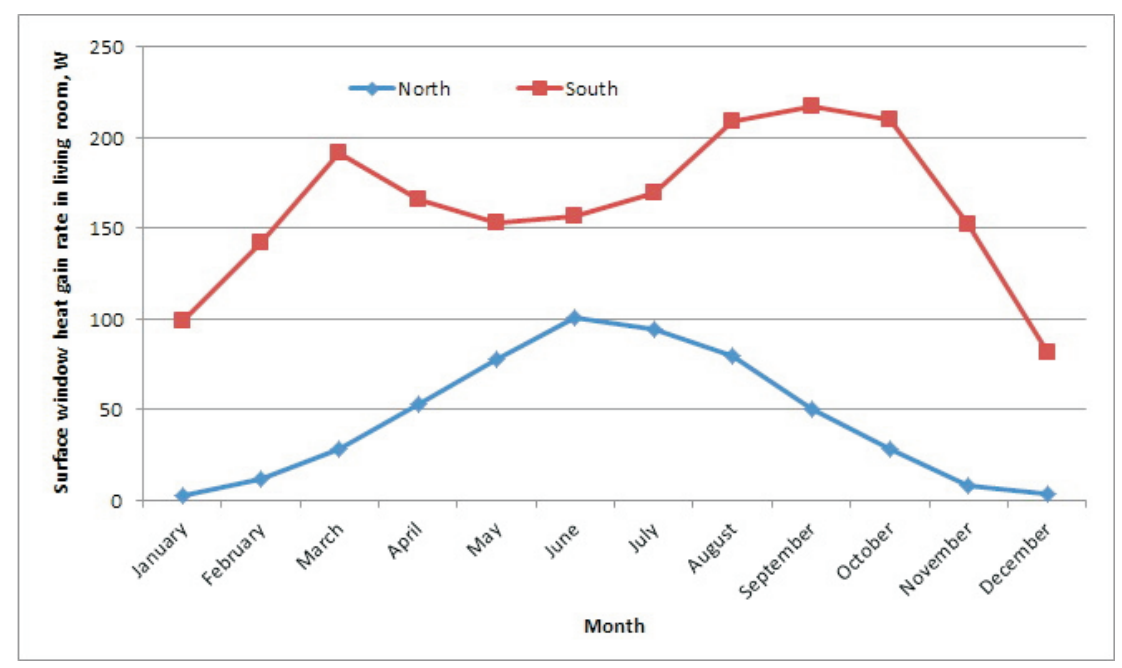

Fig. 11. Surface window heat gain rate in living room depending on the orientation of the house

Solar heat gains are smaller during summer than for september because sun is too high during summer months. During winter months sun is lower and days are shorter so then 
there is again drop in the solar heat gains. It can be seen that the north side is mostly influenced by the length of the day and that it gains more heat if the sun is higher and temperature also.

\subsection{Payback period}

In payback period cost of additional thermal insulation, 2 workers for adding thermal insulation and money saved are considered. Results for payback period are given in Table 5 .

Table 5. Thermal insulation cost, saving and payback period

\begin{tabular}{|c|c|c|c|c|}
\hline & $8 \mathrm{~cm}$ to $5 \mathrm{~cm}$ & $11 \mathrm{~cm}$ to $5 \mathrm{~cm}$ & $15 \mathrm{~cm}$ to $5 \mathrm{~cm}$ & $\begin{array}{c}15 \mathrm{~cm} \text { to } 5 \mathrm{~cm} \\
\text { new house }\end{array}$ \\
\hline Insulation cost, RSD & 24936 & 43872 & 69120 & 63120 \\
\hline Money savings, RSD & 7343 & 11445 & 14644 & 14644 \\
\hline Payback period, years & 3.40 & 3.83 & 4.72 & 4.31 \\
\hline
\end{tabular}

By this calculation it can be seen that payback period rise with increased thermal insulation layer is from 3.4 years in case of $8 \mathrm{~cm}$ vs. $5 \mathrm{~cm}$, to 4.72 years in case of $15 \mathrm{~cm}$ vs. $5 \mathrm{~cm}$ (Figure 12). New house has smaller ammount of the insulation cost because workers are used in both cases so they dont give additional cost and therefore are not considered. For new house payback period is 4.31 years.

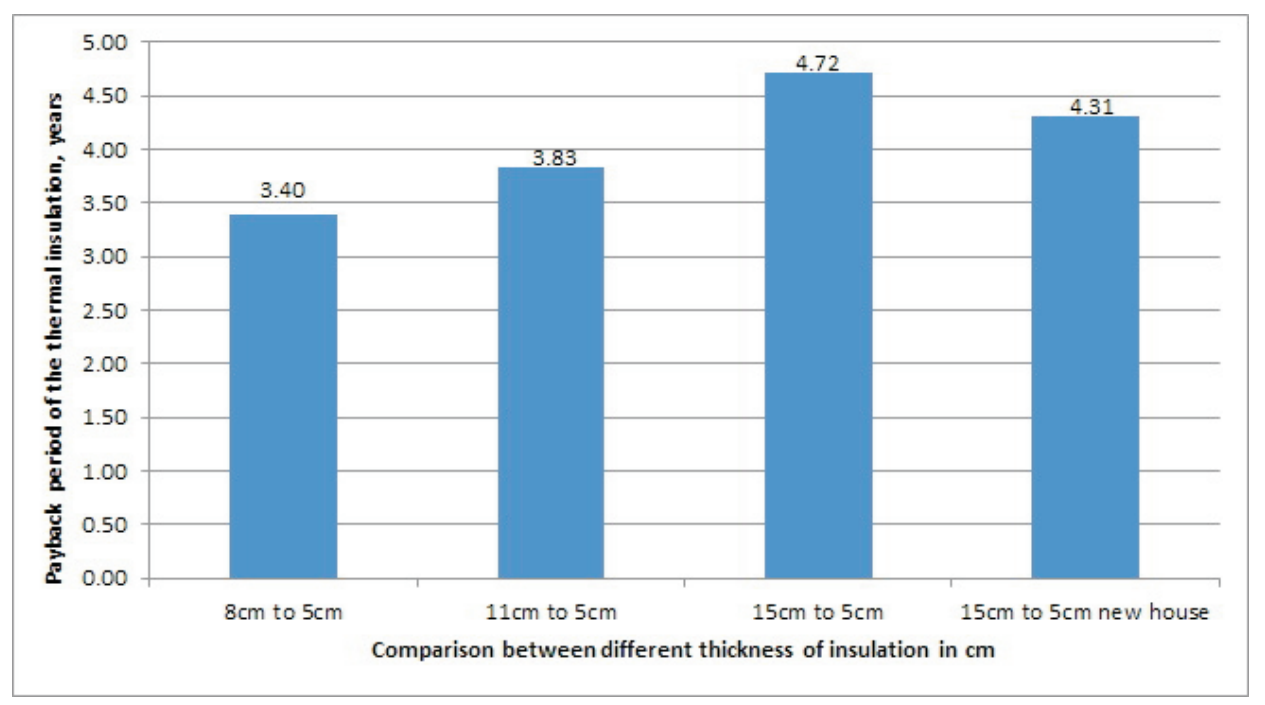

Fig. 12. Payback period of different thickness of thermal insulation

This also leads to another conclusion. Savings for $15 \mathrm{~cm}$ are double than the savings for $8 \mathrm{~cm}$ per year. This means that after 6 years user will earn more through $15 \mathrm{~cm}$ than for 8 $\mathrm{cm}$. 
Influence of new and old regulation standard for energy efficiency on thermal insulation in Serbia 143

\section{Conclusions}

This paper shows that energy consumption during year depends from thermal insulation thickness. It can be seen that thermal insulation thickness has the highest influence on the heating consumption, while it has small influence on cooling consumption.

Heating consumption savings are 31\% (35\% for south oriented) for thermal insulation with thickness of 15 in comparison to thermal insulation of $5 \mathrm{~cm}$ thickness when heating consumption is considered. With thermal insulation which satisfies the new regulation of $U<0.3(11 \mathrm{~cm})$ savings are $24 \%(27 \%)$.

Heating consumption makes $57 \%$ (52\%) in total house consumption with $5 \mathrm{~cm}$ thermal insulation thickness, while it makes $48 \%$ (42\%) of total house consumption, which is now less than half, when it has $15 \mathrm{~cm}$ thermal insulation thickness.

When orientation is considered house have high savings if its main rooms and windows are oriented toward south. This is due to solar heat gain through windows which reduces heating consumption but increases cooling consumption. When houses with thermal insulation of $5 \mathrm{~cm}$ are compared it can be seen that south oriented house is using $710 \mathrm{kWh}$ or $14 \%$ less energy for heating. But it is using $183 \mathrm{kWh}$ more for cooling. This means that it is using $527 \mathrm{kWh}$ less or $8 \%$ of total energy needed for HVAC. In case of $15 \mathrm{~cm}$ thermal insulation south oriented house is using $664 \mathrm{kWh}$ or $19 \%$ less energy for heating. But is using $189 \mathrm{kWh}$ more for cooling. This means that it is using $475 \mathrm{kWh}$ less or $10 \%$ of total energy needed for HVAC.

House oriented toward south with $15 \mathrm{~cm}$ of thermal insulation is coming close to B energy class of house which is excellent. All inspected houses are in C energy class.

Finally if payback period is considered, it can be seen that payback period rise with increased thermal insulation layer it is from 3.4 years in case when $8 \mathrm{~cm}$ thermal insulation thickness is compared to $5 \mathrm{~cm}$ thermal insulation thickness; to 4.72 years in case of $15 \mathrm{~cm}$ thermal insulation thickness compared to $5 \mathrm{~cm}$ thermal insulation thickness. For new house payback period is 4.31 years.

\section{References}

[1] SAMI A. AL-SANEA, and M. F. ZEDAN, Improving thermal performance of building walls by optimizing insulation layer distribution and thickness for same thermal mass, Applied Energy, Volume 88, Issue 9, September 2011,(2011) Pages 3113-3124, ISSN 0306-2619, 10.1016/j.apenergy.2011.02.036.

[2] Brandt Andersson, Wayne Place, Ronald Kammerud, M. Peter Scofield, The impact of building orientation on residential heating and cooling, Energy and Buildings, Volume 8, Issue 3, August 1985, (1985) Pages 205-224, ISSN 0378-7788, 10.1016/03787788(85)90005-2.

[3] M. BOJIC, F. YIK, P. SAT, Influence of thermal insulation position in building envelope on the space cooling of high-rise residential buildings in Hong Kong, Energy and Buildings, Volume 33, Issue 6, July 2001, (2001), Pages 569-581, ISSN 0378-7788, 10.1016/S03787788(00)00125-0. 
[4] M. LJ. BojIĆ, D. L. LovedAY, The influence on building thermal behavior of the insulation/masonry distribution in a three-layered construction, Energy and Buildings, Volume 26, Issue 2, (1997), Pages 153-157, ISSN 0378-7788, 10.1016/S0378-7788(96)01029-8.

[5] M. BoJIC, F. YIK, W. LeUng, Thermal insulation of cooled spaces in high rise residential buildings in Hong Kong, Energy Conversion and Management, Volume 43, Issue 2, January 2002, (2002) Pages 165-183, ISSN 0196-8904, http://dx.doi.org/10.1016/S01968904(01)00018-8.

[6] D. Crawley, L. Lawrie, F. Winkelmann, W. Buhl, Y. Joe Huang, C. Pedersen, R. Strand, R. Liesen, D. Fisher, M. Witte, J. Glazer, EnergyPlus: creating a newgeneration building energy simulation program, Energy and Buildings. 33 (2001) 319-331.

[7] Joseph C. LAm, KeVIn K. W. WAN, C. L. Tsang, LiU YANG, Building energy efficiency in different climates, Energy Conversion and Management, Volume 49, Issue 8, August 2008, Pages 2354-2366, ISSN 0196-8904, http://dx.doi.org/10.1016/j.enconman.2008.01.013.

[8] Joseph C. Lam, Kevin K. W. Wan, Dalong LiU, C. L. Tsang, Multiple regression models for energy use in air-conditioned office buildings in different climates, Energy Conversion and Management, Volume 51, Issue 12, December 2010, Pages 2692-2697, ISSN 0196-8904, http://dx.doi.org/10.1016/j.enconman.2010.06.004.

[9] New regulation for energy efficiency in Serbia starting from 2013. Website $<$ http://www.efikasnost.com/2011/09/27/pravilnik-o-energetskoj-efikasnosti/>, [accessed 10.12.2013].

[10] Miletić Marko, Dragan Cvetković, Jasmina Skerlić, Danijela Nikolić, Milorad Bojić, (2012) Optimizacija toplotne izolacije radi utede energije, Klimatizacija grejanje hlaenje $\mathrm{KGH}$, Vol.41, No.3/2012, pp. 67-70, ISSN 0350-1426, 2012

[11] David J. Mitchell, David P. Halsey, Karl Macnaughton, David E. Searle, The influence of building orientation on climate weathering cycles in Staffordshire, UK, In: Vasco Fassina, Editor(s), Proceedings of the 9th International Congress on Deterioration and Conservation of Stone, Elsevier Science B.V., Amsterdam, (2000), Pages 357-365, ISBN 9780444505170, 10.1016/B978-044450517-0/50118-5.

[12] J. MORrissey, T. MOORE, R. E. Horne, Affordable passive solar design in a temperate climate: An experiment in residential building orientation, Renewable Energy, Volume 36, Issue 2, February 2011, (2011) Pages 568-577, ISSN 0960-1481, 10.1016/j.renene.2010.08.013.

[13] Y. G. Yohanis, B. NorTON, Useful solar heat gains in multi-zone non-domestic buildings as a function of orientation and thermal time constant, Renewable Energy, Volume 27, Issue 1, September 2002, (2002) Pages 87-95, ISSN 0960-1481, 10.1016/S0960-1481(01)00163$\mathrm{X}$.

[14] Todorovi, B., Design of installations for central heating (in Serbian), Mainski fakultet Beograd, Beograd, 2005.

[15] < http://www.cis.org.rs/propisi/417?1317638041>, [accessed 15.04.2014].

[16] <http://www.eps.rs/SiteAssets/Lists/Sitemap/EditForm/20130708_EPS\%20Snabdevanje.pdf >, [accessed 15.04.2014].

[17] <http://www1.eere.energy.gov/buildings/energyplus_redirect.html>, [accessed 18.3.2013].

[18] < http://www.hidmet.gov.rs/> - Republic Hydrometeorological Service of Serbia [accessed 10.12.2013]. 
Influence of new and old regulation standard for energy efficiency on thermal insulation in Serbia 145

[19] <http://www.ursa.rs/>, [accessed 10.12.2013].

[20] <http://en.wikipedia.org/wiki/SketchUp >, [accessed 18.3.2013]. 